\title{
Hepatocyte Growth Factor Is a Mitogen for Schwann Cells and Is Present in Neurofibromas
}

\author{
Alexei Krasnoselsky, ${ }^{1}$ Mary Jo Massay, ${ }^{1}$ Marie C. DeFrances, ${ }^{2}$ George Michalopoulos, ${ }^{2}$ Reza Zarnegar, ${ }^{2}$ and \\ Nancy Ratner ${ }^{1}$ \\ 'Department of Anatomy and Cell Biology, University of Cincinnati School of Medicine, Cincinnati, Ohio 45267-0521 and \\ ${ }^{2}$ Department of Pathology, University of Pittsburgh School of Medicine, Pittsburgh, Pennsylvania 15261
}

To characterize mitogens that might contribute to Schwann cell proliferation during development or in tumors, we tested the ability of hepatocyte growth factor (HGF) to stimulate Schwann cell division in vitro. HGF is a potent mitogen for purified rat Schwann cells; DNA synthesis in rat Schwann cells was stimulated 20-40-fold by 3-10 $\mathrm{ng} / \mathrm{ml}$ HGF. Rat Schwann cells express c-met mRNA, encoding the HGF receptor, but not HGF mRNA, implying that HGF might act as a paracrine Schwann cell growth factor. HGF-stimulated Schwann cell proliferation differs from that of previously described Schwann cell mitogens in that its activity is abolished by forskolin and is not inhibited or potentiated by addition of transforming growth factor $\beta$ (TGF $\beta$ ) or fibroblast growth factor (FGF). HGF is probably not a component of the axonal signal thought to cause Schwann cell division during development, as anti-HGF neutralizing antibodies failed to block neuron-stimulated Schwann cell proliferation. In contrast, mitogenic activity present in normal human adult nerves and in neurofibromas from patients with type 1 neurofibromatosis analyzed in the absence of forskolin is largely inhibitable by anti-HGF. Thus, HGF is a novel mitogen for Schwann cells in vitro and it is present in Schwann cell tumors, suggesting a potential role for HGF after wounding of peripheral nerves or in tumor growth.

IKey words: CAMP, fibroblast growth factor, transforming growth factor, NF1, c-met, HGF, Schwann cell, mitogen]

Defining growth factors involved in Schwann cell proliferation is important in understanding interactions between Schwann cells and neurons in development, during nerve regeneration after wounding, and in formation of Schwann cell tumors. While adult Schwann cells are normally quiescent, high rates of Schwann cell division occur in the developing rat during the prenatal period after which proliferation falls gradually (Brown and Asbury, 1981; Stewart et al., 1993). Reentry into the cell cycle

\footnotetext{
Received Nov. 22, 1993; revised Apr. 15, 1994; accepted May 24, 1994.

We thank Dr. S. Degen for helpful discussions, H. Kim for supplying of some of the Schwann cells used in this work, and Drs. V. Riccardi and A. Crawford for supplying neurofibromas. This work was supported by a grant from The National Multiple Sclerosis Society and NIH Grant NS28840 (to N.R.). This project was supported in part by the Cooperative Human Tissue Network, which is funded by the National Cancer Institute.

Correspondence should be addressed to Nancy Ratner, Ph.D., Department of Anatomy and Cell Biology, University of Cincinnati, 231 Bethesda Avenue, Cincinnati, OH 45267-0521.

Copyright (C) 1994 Society for Neuroscience $0270-6474 / 94 / 147284-07 \$ 05.00 / 0$
}

occurs after nerve injury (Abercrombie and Johnson, 1946; Pellegrino et al., 1986) and in Schwann cell tumors characteristic of the inherited diseases type 1 (NF1) and type 2 neurofibromatosis. In NF1, benign peripheral nerve tumors (neurofibromas) contain axons, fibroblasts, and matrix in addition to Schwann cells (Peltonen et al., 1988). Mitogens for Schwann cells have been detected in both neurofibromas characteristic of NF1 (Ratner et al., 1990) and in inherited and sporadic vestibular Schwannomas characteristic of NF2 (Brockes et al., 1986). Neurofibromas contain basic fibroblast growth factor (bFGF) (Ratner et al., 1990) and insulin-like growth factor 2 (IGF-2) (Hansson et al., 1988) as well as an unidentified heparin-binding growth factor. The factors controlling Schwann cell proliferation in development or disease are unknown.

In vitro rat Schwann cells proliferate very slowly even in serum-containing medium. However, they can be stimulated to proliferate upon contact with the cell membrane of axon (Wood and Bunge, 1975; Salzer and Bunge, 1980). The axonal mitogen has not been identified. Recently, a Schwann cell mitogen known as glial growth factor (GGF) has been purified, cloned, and sequenced (Lemke and Brockes, 1984; Goodearl et al., 1993; Marchionni et al., 1993). Several forms of GGF are products of the neuregulin gene; neuregulin mRNA is highly enriched in neurons during development, suggesting the idea that one or more forms of neuregulin might be responsible for the ability of axons to stimulate Schwann cell division (Falls et al., 1993; Marchionni et al., 1993). Several other identified polypeptide growth factors also act as Schwann cell mitogens in vitro, including transforming growth factors $\beta 1$ and $\beta 2$ (TGF $\beta 1$ and 2), acidic (aFGF) and basic (bFGF) fibroblast growth factors, platelet-derived growth factor (PDGF) (Ratner et al., 1988; Ridley et al., 1989; Davis and Stroobant, 1990; Eccleston et al., 1990; Stewart et al., 1991; Hardy et al., 1992; Ratner et al., 1988). The action of each of these growth factors, and of neuregulin, is potentiated by forskolin or cholera toxin, agents elevating intracellular cAMP. To explain the dependence of Schwann cell mitogens on cAMP elevation in Schwann cells, it has been proposed that axonal contact might regulate cAMP levels in Schwann cells, enabling response to polypeptide growth factors (Jessen and Mirsky, 1991). cAMP treatment also increases levels of the PDGF receptor on Schwann cells in vitro (Weinmaster and Lemke, 1990), suggesting that potentiation of growth factor action may be through induction of this growth factor receptor.

In an attempt to characterize additional Schwann cell mitogens, we tested the ability of a broad specificity growth factor, hepatocyte growth factor (HGF), to stimulate Schwann cell pro- 
liferation. HGF, also known as scatter factor or hepatopoietin A, was originally identified in the serum of hepatectomized rats as a potent mitogen for cultured hepatocytes (Nakamura et al., 1984). HGF is present at high levels in normal rat serum (DeFrances et al., 1992). HGF is a heteromeric protein composed of two polypeptide chains ( $69 \mathrm{~K} \alpha$-chain and $34 \mathrm{~K} \beta$-chain) linked together by disulfide bonds. HGF shares significant amino acid sequence homology with plasminogen $(38 \%)$, and the two proteins have structural similarity: both contain intrachain disulfide loops called "kringles." HGF has four kringle domains in its $\alpha$-chain (Nakamura et al., 1989). The receptor for HGF is a $190 \mathrm{kDa}$ protein, encoded by the protooncogene known as c-met (Bottaro et al., 1991; Naldini et al., 1991). The protein (p190met) has the configuration of a type II tyrosine kinase receptor, with extracellular binding domain, transmembrane segment, and intracellular protein kinase domain.

In this report we show that recombinant human HGF is a potent mitogen for rat sciatic nerve Schwann cells. Anti-HGF antisera inhibited the mitogenic effect of recombinant $\mathrm{HGF}$ and rat serum on Schwann cells, and the mitogenic effect of extracts from neurofibromas, but failed to inhibit stimulation of Schwann cell proliferation by rat dorsal root ganglia (DRG) neurons in vitro or a mitogenic extract prepared from DRG neurons. HGFlike Schwann cell mitogen constitutes most of the serum- and forskolin-independent mitogenic activity in neurofibroma extracts.

\section{Materials and Methods}

Materials. DME, fetal calf serum, and $0.25 \%$ trypsin were obtained from GIBCO Laboratories, Grand Island, NY; forskolin, from Calbiochem-Behring Corp., San Diego, CA; basic and acidic FGF, TGF $\beta 1$, and TGF $\beta 2$, from R\&D Systems, Minneapolis, $\mathrm{MN}$; ${ }^{3} \mathrm{H}$-thymidine $(6.7$ $\mathrm{Ci} / \mathrm{mmol}$ ), from New England Nuclear, Boston, MA.

Human tissue specimens. NF1 tumor samples (plexiform and cutaneous) were obtained incidental to therapeutic surgery or at autopsy from eight patients ranging in age from 9 to 74 years, of both sexes, meeting the diagnostic criteria for NFl (Riccardi, 1992). Normal human nerve specimens $(n=2)$ were obtained at autopsy or secondary to therapeutic amputation from the Cooperative Human Tissue Network, Midwest Division.

$H G F$ and anti-HGF antisera. Recombinant HGF was prepared in a baculovirus expression system as described (Yee et al., 1993). Polyclonal antibodies to rabbit and human recombinant HGF were prepared in chicken as described by Zarnegar et al. (1990). These antisera were used for Schwann cell proliferation studies as described in the text.

Schwann cell purification and proliferation assay. Schwann cells were prepared from 1-2-d-old rat pup sciatic nerves using a slightly modified method of Brockes et al. (1979) (see Ratner et al., 1986). After complement-mediated lysis of fibroblasts, cells were plated into 96 -well plastic dishes at $10^{4}$ cells/well in DMEM with $10 \%$ fetal calf serum. $\mathrm{HGF}$, forskolin, or other growth factors were added $24-72 \mathrm{hr}$ later in defined serum-free medium, N2. The final concentration of serum in the assay was $0.5 \%$, and is referred to below as low-serum medium. ${ }^{3} \mathrm{H}$ thymidine at a concentration of $2 \mu \mathrm{Ci} / \mathrm{ml}$ was added $16-19 \mathrm{hr}$ later. Cells were fixed after an additional $24 \mathrm{hr}$ by addition of ice-cold trichloroacetic acid, solubilized in $\mathrm{NaOH}$, and counted in a scintillation counter, as described in Nordlund et al. (1992).

Total RNA extraction and reverse-transcriptase polymerase chain reaction $(P C R)$. Total RNA was extracted from $11 \times 10^{7}$ Schwann cells, amplified from primary rat Schwann cells, as described by Porter et al. (1987), by exposure to forskolin and serum on polylysine-coated plastic; GGF was replaced by bovine brain membrane extract (Nordlund et al., 1992). The cells were homogenized using a Brinkmann Polytron homogenizer in RNAzol B (Biotecx Labs, Inc., Houston, TX) according to the manufacturer's recommendations. For each reaction, I $\mu \mathrm{g}$ of total RNA was reverse transcribed to cDNA using the GeneAmp preamplification system (Perkin Elmer Cetus, Norwalk, CT). The resulting cDNA was then subjected to 40 cycles of PCR using a DNA Thermal Cycler 480 (Perkin-Elmer Cetus, Norwalk, CT). “AmpliTaq” DNA polymerase
(Perkin Elmer Cetus, Norwalk, CT), and primers for HGF, c-met, or actin were used. The HGF primers amplify a 690 base pair (bp) fragment. The sequences of the primers correspond to the sequence for HGF published by Miyazawa et al. (1989) and are as follows: HGF forward primer $(b p+710)$, 5'-ATCAGACACCACACCGGCACAAAT-3'; HGF reverse primer (bp + 1400), 5'-GAAATAGGGCAATAATCCCAAGGAA-3'.

The c-met primers amplify an $836 \mathrm{bp}$ fragment. The sequences of the primers correspond to the sequence of c-met published by Chan et al. (1988) and are as follows: c-met forward primer (bp + 142), 5'-GCAGAAACCCCCATCCAGAATGTC-3'; c-met reverse primer (bp + 978), 5'-GGCCCCTGGTTTACTGACATACGC-3'.

It has been previously shown that these primer pairs specifically amplify transcripts for HGF and c-met when present in both human and rat tissues (DeFrances et al., 1992). Amplified products have been cloned and sequenced, confirming their identities. The identity of each PCR product has been confirmed by ligation into the pCR II vector (Invitrogen Corp., San Diego, CA) and sequencing using "Sequenase" (USB, Cleveland, $\mathrm{OH}$ ). Human $\beta$ - actin primers purchased from Clontech Laboratories, Inc. (Palo Alto, CA) amplify an approximately $1000 \mathrm{bp}$ fragment. These primers were included to ensure that RNA from each sample was intact. Reactions using each set of primers were performed for Schwann cell RNA in the absence of reverse transcriptase to ensure that no contamination with plasmid DNA or genomic DNA had occurred (data not shown). Also, reactions were carried out omitting RNA to ensure that primers were not contaminated with plasmid DNA. Human placental total RNA was included as a positive control for all primers. After amplification and extraction using a one-step chloroform procedure, each sample was applied to a $1 \%$ agarose/ethidium bromide gel at $100 \mathrm{~V}$. The resulting gel was photographed using UV illumination.

Preparation of dorsal root ganglion neuron-Schwann cell cocultures and Schwann cell proliferation. Preparation of embryonic rat neurons in coculture with Schwann cells has been described (Ratner et al., 1986). After 2-3 weeks Schwann cells were added to the dorsal root ganglia neuron culture with or without anti-HGF antiserum. After $3 \mathrm{hr}$ serumcontaining medium was substituted with a defined, serum-free medium (N2) with or without anti-HGF antiserum, and ${ }^{3} \mathrm{H}$-thymidine was added at $2 \mu \mathrm{Ci} / \mathrm{ml}$ for $24 \mathrm{hr}$. Cultures were fixed, processed for autoradiography, stained with toluidine blue, and analyzed for percentage of labeled cell nuclei. Dorsal root ganglion neuronal membrane extract was prepared as described in Ratner et al. (1988). Neurofibroma extracts and normal human nerve extracts were prepared as described in Method II in Ratner et al. (1990). Aliquots were dialyzed against PBS for 5-6 hr and stored at $-70^{\circ} \mathrm{C}$ prior to addition to Schwann cells.

\section{Results}

HGF is mitogenic for Schwann cells

HGF consistently induced $20-40$-fold stimulation of DNA synthesis in Schwann cells in low-serum medium (less than $0.5 \%$ serum); half-maximal stimulation was obtained with HGF at concentrations $3-5 \mathrm{ng} / \mathrm{ml}$ with maximum at $10 \mathrm{ng} / \mathrm{ml}$ (Fig. $1 A$ ). These concentrations are in the same range as those required to stimulate proliferation of rat hepatocytes in a serum-free medium (Michalopoulos and Zarnegar, 1992). When fetal bovine serum $(10 \%)$ was added to the Schwann cell proliferation assay, HGF stimulated a 5-10-fold increase in DNA synthesis with the same half-maximal and maximal stimulation concentrations as in low-serum medium (Fig. $1 B$ ). The lower degree of stimulation can be explained by higher basal proliferation in $10 \%$ serum. As shown in Figure $1 A$, at concentrations higher than $10 \mathrm{ng} / \mathrm{ml}$ the magnitude of HGF-stimulated Schwann cell proliferation declincd in both low- and high-scrum medium. This decrease was not a result of toxicity, as cell number in the cultures remained constant over the duration of the bioassay even at $20 \mathrm{ng} / \mathrm{ml} \mathrm{HGF}$ (not shown). Thus, HGF is a novel growth factor for Schwann cells.

\section{The mitogenic effect of $\mathrm{HGF}$ is inhibited by forskolin}

To determine if HGF activity, like that of other Schwann cell mitogens, could be enhanced by elevation of intracellular cAMP, 

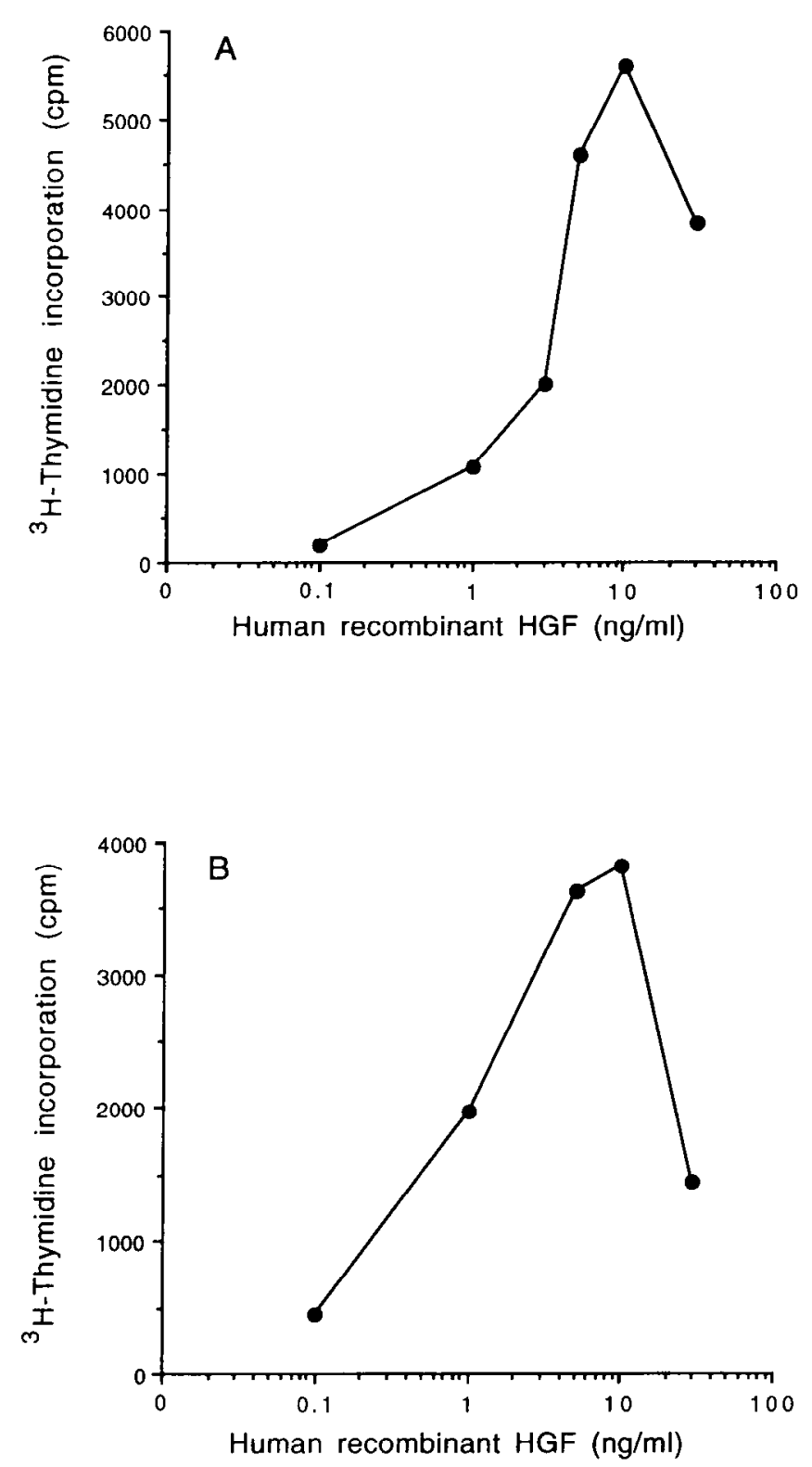

Figure 1. Stimulation of DNA synthesis in rat sciatic nerve Schwann cells by human recombinant HGF. Various concentrations of HGF were added to primary Schwann cells in serum-free N2 medium $(A)$ or $10 \%$ fetal bovine scrum $(B)$. Each panel shows data from one of five separate experiments. Primary Schwann cell cultures were prepared independently for each experiment and varied slightly in the extent of basal proliferation and the degree of stimulation. Each value represents the mean of duplicate observations not differing from the mean by more than $10 \%$.

HGF was added to rat Schwann cells in combination with forskolin. Under conditions tested, $1 \mu \mathrm{M}$ forskolin alone stimulated DNA synthesis very slightly and dramatically potentiated the mitogenic effect of bFGF and TGF $\beta(1$ or 2) (Fig. 2A,R);5 $\mu \mathrm{M}$ forskolin inhibited the action of TGF $\beta$, but synergized with FGF, corroborating previous results (data not shown) (Ridley et al., 1989; Davis and Stroobant, 1990). In contrast, when added to Schwann cells in combination with HGF $(5 \mathrm{ng} / \mathrm{ml}), 1$ $\mu \mathrm{M}$ forskolin abolished the ability of HGF to stimulate Schwann cell proliferation (Fig. 3); $0.1 \mu \mathrm{M}$ forskolin had no effect (not shown), while $0.5 \mu \mathrm{M}$ forskolin gave half-maximal inhibition (Fig. 2A).
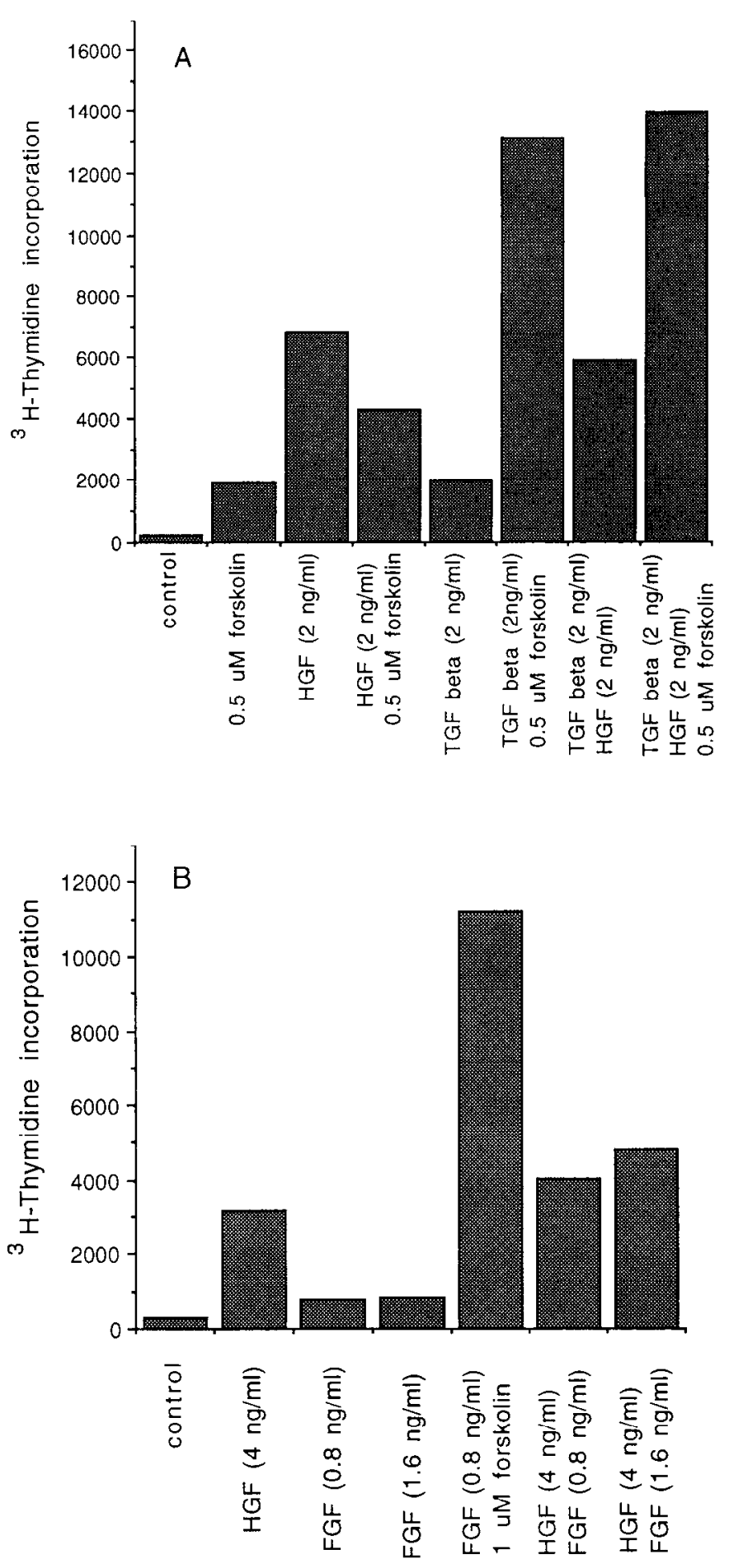

Figure 2. TGF $\beta$ and bFGF do not inhibit or potentiate HGF-stimulated Schwann cell proliferation. Stimulation of DNA synthesis in cultured Schwann cells in N2 medium was analyzed in the presence of $\mathrm{HGF}, \mathrm{HGF}+$ forskolin, TGF $\beta$, TGF $\beta$ + forskolin, HGF + TGF $\beta$, or $\mathrm{HGF}+\mathrm{TGF} \beta$ plus forskolin $(A)$. In $B$, combinations of HGF and basic FGF are shown. Each column represents results of duplicate observations.

Addition of TGF $\beta 1$ with either bFGF or PDGF results in the induction of DNA synthesis in Schwann cells (Davis et al., 1991; Shubert, 1992). We tested whether bFGF or TGF $\beta$ synergize with HGF in stimulation of Schwann cell proliferation. Schwann cells were exposed to HGF ( 2 or $4 \mathrm{ng} / \mathrm{ml}$ ) in combination with 


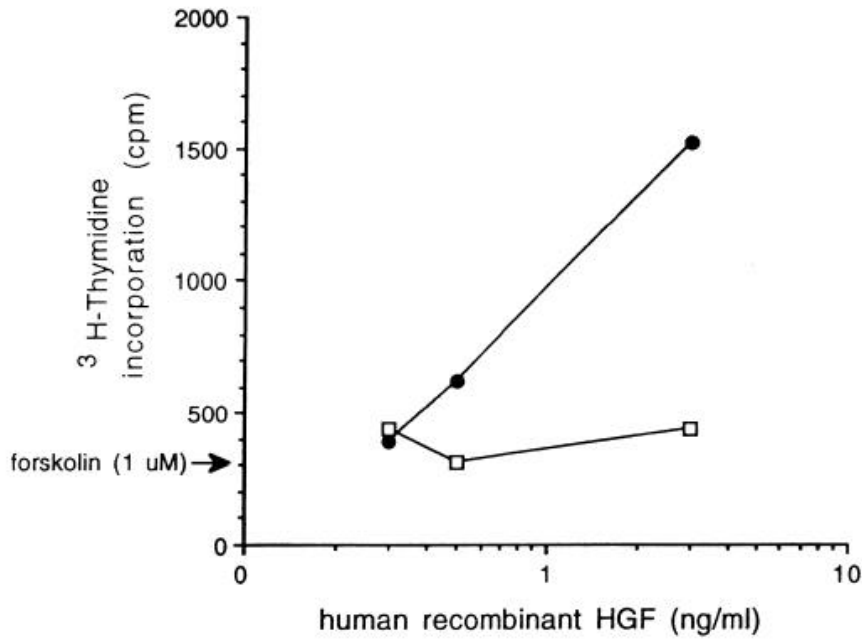

Figure 3. The mitogenic activity of HGF on Schwann cells is inhibited by forskolin. Stimulation of DNA synthesis in rat Schwann cells by human recombinant $\mathrm{HGF}$ was analyzed in $\mathrm{N} 2$ medium in the absence (๑) or presence ( $\square$ ) of $1 \mu \mathrm{M}$ forskolin. Each value represents the mean of duplicate observations not differing from the mean by more than $10 \%$. Arrow denotes proliferation stimulated by $1 \mu \mathrm{M}$ forskolin alone.

bFGF $(0.8$ and $1.6 \mathrm{ng} / \mathrm{ml})$ or TGF $\beta 1(2 \mathrm{ng} / \mathrm{ml}) ; \mathrm{bFGF}$ and TGF $\beta 1$ were additive with HGF on Schwann cell proliferation at the concentrations used. Neither bFGF nor TGF $\beta$ potentiated or inhibited the action of HGF (Fig. $2 A, B$ ).

\section{$H G F$ and c-met $m R N A$ expression in neonatal rat Schwann cells}

We examined whether HGF and/or c-met mRNA are expressed in rat Schwann cells using the reverse transcriptase PCR. Total RNA was extracted from cultured Schwann cells, and reverse transcription and PCR were carried out as described in Materials and Methods. PCR products were fractionated on 1\% agarose/ ethidium bromide gel (Fig. 4). Expected amplified fragments of 690 base pairs for HGF (Fig. 4, lane F), 836 base pairs for c-met (lane E) and approximately 1000 base pairs for human $\beta$-actin (lanes G) were observed in the control experiments using human placenta RNA. No expression of HGF mRNA was found in Schwann cells (lane C); however, the message for c-met was present in both control and rat Schwann cell RNA preparations (lane B). The identity of the c-met transcripts were confirmed by sequencing of the PCR product (not shown).

\section{Mitogen from dorsal root ganglion neurons is immunologically different from $\mathrm{HGF}$}

Two different anti-HGF antisera blocked proliferation of Schwann cells stimulated by recombinant HGF. In control experiments to confirm the specificity of the antisera, neither antiHGF antisera inhibited Schwann cell proliferation stimulated by bFGF, by TGF $\beta$, or by crude glial growth factor (not shown). Neither anti-HGF antisera inhibited proliferation of Schwann cells in coculture with intact dorsal root ganglia neurons, even at 10 times higher concentrations of anti-HGF antisera than those used to inhibit proliferation of Schwann cells induced by HGF itself (Fig. 5). An anti-rabbit HGF and anti-human HGF antisera were used on the rat tissue preparation (dorsal root ganglia were prepared from rat embryos), the ability of the antibodies to recognize rat HGF was confirmed using normal rat serum; HGF has been shown to be present in rat serum in

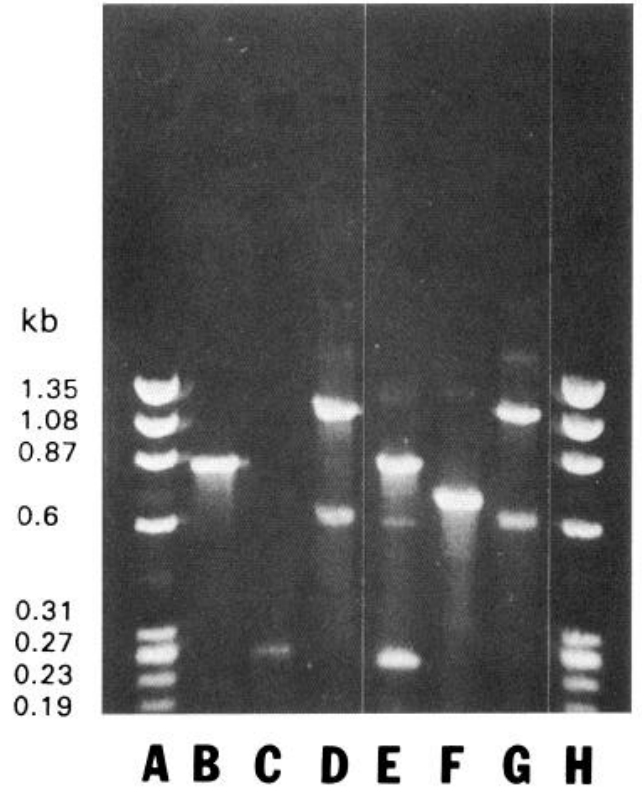

Figure 4. Analysis of rat Schwann cell mRNA by reverse-transcriptase PCR (as described in Materials and Methods). Lanes $A$ and $H$, molecular size standards $-\Phi$ X174 RF DNA/HaeIII (GIBCO-Bethesda Research Labs, Gaithersburg, MD) with fragments lengths as follows: $1.35 \mathrm{~kb}$, $1.08 \mathrm{~kb}, 0.87 \mathrm{~kb}, 0.60 \mathrm{~kb}, 0.31 \mathrm{~kb}, 0.27 / 0.28 \mathrm{~kb}, 0.23 \mathrm{~kb}, 0.19 \mathrm{~kb}, 0.12$ $\mathrm{kb}, 0.07 \mathrm{~kb}$ (the last two fragments are not visible in the figure). Lanes $B-D$, Schwann cell mRNA with reverse transcriptase using the following primers: c-met $(B), \operatorname{HGF}(C), \beta$-actin $(D)$. Lanes $E-G$, RNA from human placenta, which expresses both HGF and c-met mRNA, using the following primers: c-met $(E), \operatorname{HGF}(F)$, and $\beta$-actin $(G)$. The nature of the $0.27 \mathrm{~kb}$ band in lane $C$ is unknown and likely to represent a PCR artifact. Schwann cell RNA was also amplified in the absence of reverse transcriptase with each primer set to omit the possibility of plasmid/product contamination. Additionally, the primers were examined for plasmid/ product contamination by carrying out reactions in the absence of RNA. Both experiments showed no plasmid/product contaminations had occurred (not shown). This figure is a composite photograph of a single gel.

measurable amounts (DeFrances et al., 1992). Addition of normal rat serum to rat Schwann cells resulted in the stimulation of DNA synthesis; anti-HGF antiserum inhibited up to $70 \%$ of the mitogenic activity of normal rat serum. As it remained possible that HGF was bound to cell membranes in a conformation undetected by antibodies, we prepared membrane extracts from cultured rat dorsal root ganglia in order to get the mitogen in solubilized form. These extracts induced DNA synthesis in quiescent Schwann cells, but the mitogenic activity of these extracts was not inhibited by anti-HGF antisera. These data strongly argue against the idea of HGF (or HGF-like protein) being a required component of the axonal membrane mitogen.

\section{HGF-like protein mitogenic for Schwann cells can be extracted from human neurofibromas}

To determine if HGF is present in and might contribute to mitogenic activity found in normal nerve or Schwann cell tumors, high salt extracts were prepared from two normal adult human nerves and from eight neurofibromas from NF1 patients, dialyzed against PBS, and added to rat Schwann cells in the ${ }^{3} \mathrm{H}$ thymidine incorporation assay. Normal nerve and six of eight neurofibromas tested contained dose-dependent mitogenic activity for Schwann cells, confirming previous results (Ratner et 


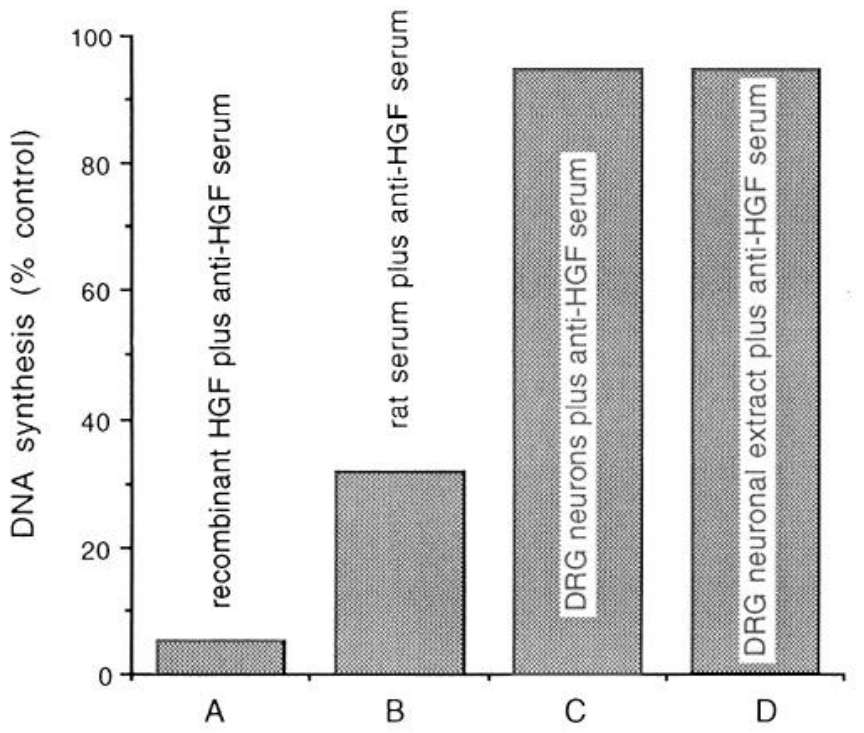

Figure 5. Neutralizing anti-HGF sera do not inhibit the activity of the neuronal mitogen for Schwann cells. $A$, Chicken anti-human HGF antiserum (1:1000) was added to rat Schwann cells together with $10 \mathrm{ng} /$ $\mathrm{ml}$ recombinant HGF. Data are presented as the stimulation of DNA synthesis in antibody treated wells compared to control, parallel, Schwann cell cultures to which HGF alone was added. Chicken anti-rabbit HGF antiserum (1:1000) also inhibited HGF-stimulated of DNA synthesis by cultured rat Schwann cells (not shown); nonimmune chicken serum did not inhibit HGF-stimulated Schwann cell proliferation (not shown). $B$, Rat serum, unlike many lots of FCS, is mitogenic for Schwann cells. Stimulation of SC proliferation in $10 \%$ rat serum was equivalent to that stimulated by $10 \mathrm{ng} / \mathrm{nl} \mathrm{HGF}$. Anti-human HGF antiserum (1:1000) partially inhibited the mitogenic effect of rat serum on Schwann cells. $C$, Anti-human HGF antiserum (1:100) was added to cocultures of DRG neurons at the time of seeding with Schwann cells. Cultures were pulsed with ${ }^{3} \mathrm{H}$-thymidine; after $24 \mathrm{hr}$ cultures were fixed and subjected to autoradiography. Labelling index of Schwann cells in these cultures was $75 \%$, identical to control cultures without antisera or in the presence of nonimmune sera. $D$, DRG neuronal extract was added to Schwann cells in the presence or absence of anti-rabbit HGF antiserum (1:1000). TCAprecipitable counts were the same in the presence or absence of the antibody.

al., 1990; data not shown). Activity in normal nerve extracts and in all six active tumor extracts was inhibitable by anti-HGF (Fig. 6). Inhibition ranged from $60 \%$ to $97 \%$ of the total activity in two or three separate analyses of each extract using various doses of extract. Thus, HGF (or HGF-like protein) is a new Schwann cell mitogen present in normal adult nerve and in neurofibromas.

We also found that neurofibroma and normal nerve extracts contain mitogens potentiated by forskolin (Fig. 6A). Forskolin at concentrations of $0.5-5 \mu \mathrm{M}$ dramatically potentiated the activity of all extracts tested (Fig. 7); forskolin-stimulated activity was not inhibited by anti-HGF antibodies, suggesting that HGF did not contribute to the forskolin-stimulated activity in neurofibromas.

\section{Discussion}

We have shown that HGF is a potent mitogen for rat sciatic nerve Schwann cells. The ability to stimulate Schwann cell proliferation vigorously in low-serum medium $(<0.5 \%$ serum) distinguishes HGF from other defined Schwann cell mitogens (Ratner et al., 1988; Ridley et al., 1989; Eccleston et al., 1990; Stewart et al., 1991; Hardy et al., 1992; Schubert, 1992). HGF
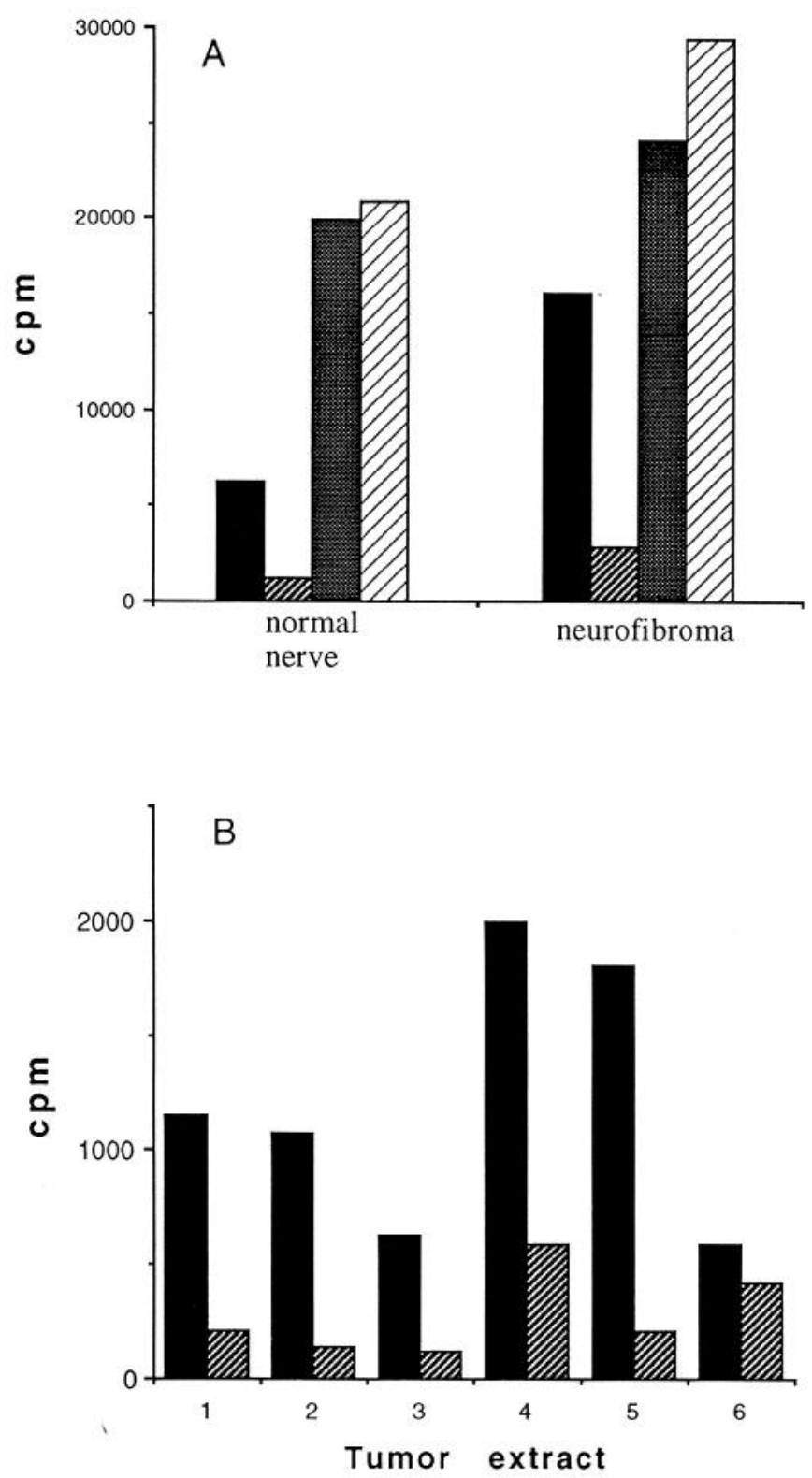

Figure 6. Inhibition of Schwann cell mitogenic activity of normal nerve and neurofibroma extracts by anti-HGF antibodies. Extracts from normal nerve and six different neurofibromas prepared as described in Materials and Methods were tested in Schwann cell proliferation assay. $A$, Extracts from normal nerve and a representative neurofibroma were tested in the presence (hatched bars) or absence (solid bars) of anti-HGF antibodies (used at 1:200 dilution) without (solid and dark hatched bars) and with $2 \mu \mathrm{M}$ forskolin (stippled and light hatched bars). B. Extracts of six different neurofibromas were tested in the presence (hatched bars) or absence (solid bars) of anti-HGF antibodies (used at 1:200 dilution). Abscissa denotes tumor number. Each column represents the mean of duplicate observations in one representative experiment.

at concentrations above $10 \mathrm{ng} / \mathrm{ml}$ showed reduced ability to stimulate Schwann cell proliferation, in contrast to PDGF, TGF $\beta$, and GGF, all of which are characterized by a sigmoidal doseresponse curve with a characteristic plateau of saturation (Ridley et al., 1989; Davis and Stroobant, 1990; Eccleston et al., 1990; Stewart et al., 1991).

An important feature of HGF's mitogenic action is the effect of the cAMP-elevating agent forskolin on HGF induction of DNA synthesis in Schwann cells. In contrast to previously de- 
fined Schwann cell mitogens, HGF activity is abolished by 1 $\mu \mathrm{M}$ forskolin and lower concentrations of forskolin did not potentiate the activity. cAMP can modulate response of Schwann cells to mitogen by upregulating PDGF receptors (Weinmaster and Lemke, 1990). It is possible that increasing cAMP downregulates $\mathrm{c}$-met. Combination of $\mathrm{HGF}, \mathrm{TGF} \beta$, and forskolin (1 $\mu \mathrm{M}$ ) elicited the same mitogenic response as TGF $\beta$ plus forskolin alone, suggesting that IIGF induced DNA synthesis in Schwann cells was completely abolished and did not interfere with TGF $\beta$ / forskolin-induced Schwann cell proliferation. We also did not observe an inhibitory effect of TGF $\beta$ on HGF-induced Schwann cell proliferation, although Zarnegar and Michalopoulos (1989) showed that stimulation of DNA synthesis in rat hepatocytes by $\mathrm{HGF}$ is inhibited by TGF $\beta$.

It has been shown that axonal cell membranes contain an unidentified mitogen for Schwann cells (Salzer and Bunge, 1980; Ratner et al., 1987). Like HGF, this factor is heparin binding (Ratner et al., 1988) and active in the absence of serum or forskolin. Antisera that completely block the activity of HGF on Schwann cells failed to inhibit the mitogenic activity of neuronal membrane extracts or Schwann cell proliferation in neuron-Schwann cell cocultures, thought to mimic Schwann cell proliferation during development. Thus, HGF is unlikely to be a component of the Schwann cell proliferation that occurs in peripheral nerve development. This is consistent with the idea that axons elevate cAMP in Schwann cells, enabling response to many polypeptide growth factors; when in contact with axons, Schwann cells may be refractory to HGF. There is also no evidence for concentration of HGF in developing peripheral nerves during the period of maximal Schwann cell proliferation in developing rats (DeFrances et al., 1992).

We did not detect HGF mRNA in rat Schwann cells, although HGF message and HGF are present in many tissues, including the brain (Tashiro et al., 1990; Zarnegar et al., 1990; DeFrances et al., 1992). Thus, it is unlikely that HGF serves as an autocrine Schwann cell growth factor, at least under the conditions tested. This is consistent with observations of Sonnenberg et al. (1993), who found that no tissue studied contained $\mathrm{HGF}$ and $\mathrm{c}$-met transcripts in the same cells.

Schwann cells are quiescent in normal adult nerve ( $\Lambda$ bercombie and Johnson, 1946). We found that normal adult human nerve extracts contain HGF (or HGF-like protein). It is known that HGF may be stored or secreted by cells in an inactive form. Pro-HGF (including some commercially available preparations sold mostly as precursor) is not active on Schwann cells (data not shown). Injury has been shown to cause proteolytic activation of HGF precursor in liver and kidney (Miyazawa et al., 1994). Thus, HGF may become available to Schwann cells after injury.

We have also shown that HGF is present in human neurofibromas, where it constitutes $60-97 \%$ of the Schwann cell mitogenic activity extracted from these tumors when assayed in the absence of forskolin. Other mitogens for Schwann cells are also detectable in neurofibromas: IGF-1 is present in neurofibromas (Hansson et al., 1988) and has been recently shown to be a mitogen for Schwann cells in the presence of forskolin (Schumacher et al., 1993). We previously have found bFGF and an unidentified heparin-binding Schwann cell mitogen in neurofibromas (Ratner et al., 1990). As HGF binds to heparin (Zarnegar et al., 1990), it is likely that the previously unidentified heparin-binding, non-FGF mitogenic activity in these tumors is contributed by HGF or HGF-like protein. Mitogenic activity

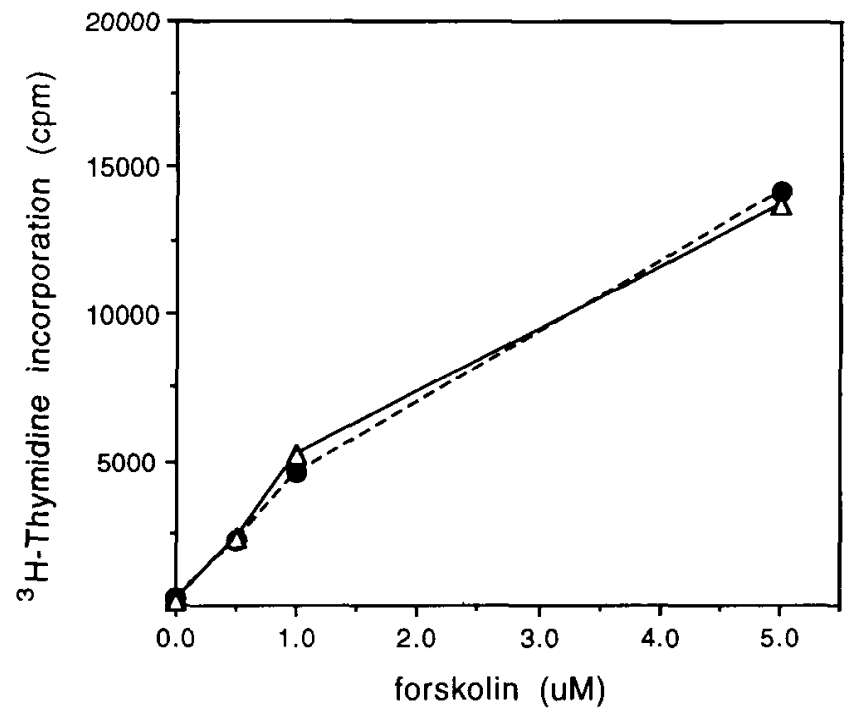

Figure 7. Forskolin synergizes with neurofibroma extract in stimulation of Schwann cell proliferation. A suboptimal dose $(30 \mu \mathrm{g} / \mathrm{ml})$ of ncurofibroma extract was added to rat Schwann cells together with various concentrations of forskolin (open triangles). Forskolin-stimulated activity of neurofibroma extract was not inhibited by simultaneous addition of anti-HGF antibody (1:200) (solid circles). Similar results were obtained using all neurofibroma extracts tested.

in neurofibroma extracts assayed in the presence of forskolin could not be inhibited by anti-HGF antibodies, corroborating the idea that non-HGF Schwann cell mitogens, including bFGF and IGF-1, are present in neurofibromas.

Neurofibromas consist of up to $80 \%$ Schwann cells (Peltonen et al., 1988), suggesting that Schwann cell proliferation is an important component of neurofibroma formation. It will be important to localize Schwann cell mitogens, and their receptors, within neurofibromas to determine what cells synthesize and secrete these growth factors in order to begin to analyze the relevance of specific growth factors to tumor formation. We have shown in two reports that $\mathrm{HGF}$ is present in measurable amounts in normal rat serum (DeFrances ct al., 1992; Michalopoulos and Zarnegar, 1992) and here that HGF is responsible for $70 \%$ of rat serum's mitogenic activity on Schwann cells. Thus, it is possible that HGF in neurofibromas is derived from blood (which also might be a source of other growth factors detectable in neurofibromas). It is possible that some NF1 manifestations, including formation of neurofibromas, result from abnormal expression or distribution of HGF.

\section{References}

Abercrombie M, Johnson ML (1946) Quantitative histology of Wallerian degeneration. J Anat 80:37-50.

Bardelli A, Miana F, Gout I, Fry M, Waterfield MD, Comoglio PM, Ponzetto C (1992) Autophosphorylation promotes complex formation of recombinant hepalocyte growth factor receptor with cytoplasmic effectors containing SH2 domains. Oncogene 7:1973-1978.

Bottaro DP, Rubin JS, Faletto DL, Chan AML, Kmiecick TE, Vande Woude GF, Aaronson SA (1991) Identification of the hepatocyte growth factor receptor as the c-met proto-oncogene product. Science 251:802-804.

Brockes JP, Fields KL, Raff MC (1979) Studies on cultured rat Schwann cells. I. Establishment of purified populations from cultures of peripheral nerve. Brain Res 165:105-118

Brockes JP, Breakfield XO, Martuza RL (1986) Glial growth factorlike activity in Schwann cell tumors. Ann Neurol 20:317-322. 
Brown MJ, Asbury AK (198I) Schwann cell proliferation in the postnatal mouse: timing and topography. Exp Neurol 74:170-186.

Chan AM-L, King HWS, Deakin EA, Tempest PR, Hilkens J, Kroezen V, Edwards DR, Wills AJ, Brookes P, Cooper CS (1988) Characterization of the mouse met proto-oncogene. Oncogene 2:593-599.

Davis JB, Stroobant P (1990) Platelet-derived growth factors and fibroblast growth factors are mitogens for rat Schwann cells. J Cell Biol 110:1353-1360.

Davis JB, Shores AJ, Watts AG, Stroobant P (1991) TGF $\beta$ as a potential regulator of Schwann cell proliferation. Soc Neurosci Abstr $17: 753 \mathrm{a}$.

DeFrances MC, Wolf HK, Michalopoulos GK, Zarnegar R (1992) The presence of hepatocyte growth factor in the developing rat. Development 116:387-395.

Fccleston PA, Collarini EJ, Jessen KR, Mirsky R, Richardson WD (1990) Schwann cells secrete a PDGF-like factor: evidence for an autocrine growth mechanism involving PDGF. Eur J Neurosci 2:985992.

Eccleston PA, Funa K, Heldin C-H (1993) Expression of plateletderived growth factor (PDGF) and PDGF $\alpha$-/and $\beta$-receptors in the peripheral nervous system: an analysis of sciatic nerve and dorsal root ganglia. Dev Biol 155:459-470.

Falls DL, Rosen KM, Corfas G, Lane WS, Fischbach GD (1993) ARIA, a protein that stimulates acetylcholine receptor synthesis, is a member of the neu ligand family. Cell 72:801-815.

Goodearl ADJ, Davis JB, Mistry K, Minghetti L, Otsu M, Waterfield MD, Stroobant $P$ (1993) Purification of multiple forms of glial growth factor. J Biol Chem 268:18095-18102.

Hansson HA, I auritzen C, I ossing C, Petruson K (1988) Somatomedin $\mathrm{C}$ as a tentative pathogenic factor in neurofibromatosis. Scand J Plast Reconstr Surg 22:7-13.

Hardy M, Reddy UR, Pleasure D (1992) Platelet-derived growth factor and regulation of Schwann cell proliferation in vivo. J Neurosci Res $31: 254-262$.

Igawa T, Kanda S, Kanetake H, Saituh Y, Ichihara A, Tomita Y, Nakamura $T$ (1991) Hepatocyte growth factor is a potent mitogen for cultured rabbit tubular epithelial cells. Biochem Biophys Res Commun 174:831-838.

Jessen KR, Mirsky R (1991) Schwann cell precursors and their development. Glia 4:185-194.

Kan M, Zhang G, Zarnegar R, Michalopoulos GK, Myoken Y, McKeenan WL, Stevens JI (1991) Hepatocyte growth factor/hepatopoietin A stimulates the growth of rat proximal tubule epithelial cells (RTPE), art nonparenchymal liver cells, human melanoma cells, mouse keratinocytes and stimulates anchorage-independent growth of SV40 transformed RPTE. Biochem Biophys Res Commun 174:331-337.

Lemke GE, Brockes JP (1984) Identification and purification of glial growth factor. J Neurosci 4:75-83.

Marchionni M (1993) Glial growth factors are alternatively spliced erbB2 ligands expressed in the nervous system. Nature 362:312-318.

Michalopoulos GK (1990) Liver regeneration: molecular mechanisms of growth control. FASEB J 4:240-249.

Michalopoulos GK, Zarnegar R (1992) Hepatocyte growth factor. Hepatology 15:149-155.

Miyazawa K, Tsubouchi H, Naka D, Takahashi K, Okigaki M, Arakaki L, Nakyama H, Hirono S, Sakiymam O, Takahashi K, Gohda E, Daikura $Y$, Kitamura N (1989) Molecular cloning and sequence analysis of cDNA for human hepatocyte growth factor. Biochem Biophys Res Commun 163:967-973.

Miyazawa K, Shimomura T, Naka D, Kitamura N (1994) Proteolytic activation of hepatocyte growth factor in response to tissue injury. $J$ Biol Chem 269:8966-8970.

Nakamura T, Nawa K, Ichihara A (1984) Partial purification and characterization of hepatocyte growth factor from serum of hepatectomized rats. Biochem Biophys Res Commun 122:1450-1459.

Nakamura T, Nishizawa T, Hagiya M, Seki T, Shimonishi M, Sugimura A, Tashiro K, Shimizu S (1989) Molecular cloning and sequence analysis of cDNA for human hepatocyte growth factor. Nature 342 : $440-443$.

Naldini L, Vigna E, Narshimhan RP, Gaudino G, Zarnegar R, Michalopoulos GK, Comoglio PM (1991) Hepatocyte growth factor (HGF) stimulates the tyrosine kinase activity of the receptor encoded by the proto-oncogene c-met. Oncogene 6:501-504.

Nordlund M, Hong DG, Fei X, Ratner N (1992) Schwann cells and cells of oligodendrocyte lineage proliferate in response to a 50,000 dalton membrane-associated mitogen present in developing brain Glia 5:182-192.

Pcllcgrino RG, Politis MG, Ritchie JM, Spencer PS (1986) Events in degenerating cat peripheral nerve: induction of Schwann cell $S$ phase and its relation to nerve fibre degeneration. J Neurocytol 15:17-28.

Peltonen J, Jaakkola S, Lebwohl M, Revnall S, Riskeli L, Virkanen I, Uitto $T$ (1988) Cellular differentiation and expression of matrix genes in type I neurofibromatosis. Lab Invest 59:760-771.

Porter S, Glaser L, Bunge RP (1987) Release of autocrine growth factor by primary and immortalized Schwann cells. Proc Natl Acad Sci USA 84:7768-7772.

Ratner N, Elbein A, Bunge MB, Porter S, Bunge RP, Glaser L (1986) Specific asparagine-linked oligosaccarides are not required for certain neuron-neuron and neuron-Schwann cell interactions. J Cell Biol 103:159-170

Ratner N, Wood PM, Bunge RP, Glaser L (1987) Further characterization of the neuronal cell surface molecule mitogenic for Schwann cells. In: Glial neuronal communication in development and regulation (Athlaus HH, Seifer W, eds), pp 684-698. New York: Springer.

Ratner N, Hong D, Lieberman MA, Bunge RP, Glaser L (1988) The neuronal cell-surface molecule mitogenic for Schwann cells is a heparin-binding protein. Proc Natl Acad Sci USA 85:6992-6996.

Ratner N, Lieberman MA, Riccardi VM, Hong D (1990) Mitogen accumulation in von Recklinghausen neurofibromatosis. Ann Neurol 27:298-303.

Riccardi VM (1992) Neurofibromatosis: phenotype, natural history, and pathogenesis.

Ridley AJ, Davis JB, Stroobant P, Land H (1989) Transforming growth factors- $\beta 1$ and $\beta 2$ are mitogens for rat Schwann cells. J Cell Biol 109: 3419-3424.

Salzer JL, Bunge RP (1980) Studies of Schwann cell proliferation. I. An analysis in tissue culture or proliferation during development Wallerian degeneration, and direct injury. J Cell Biol 84:739-752.

Salzer JL, Williams AK, Glaser L, Bunge RP (1980) Studies of Schwann cell proliferation. II. Characterization of the stimulation and specificity of the responses to a neurite membrane fraction. J Cell Biol 84 767-778.

Schubert D (1992) Synergistic interactions between transforming growth factor beta and fibroblast growth factor regulate Schwann cell mitosis. J Neurobiol 23:143-148.

Schumacher M, Jung-Testas I, Robel P, Baulieu E-E (1993) Insulinlike growth factor I: a mitogen for rat Schwann cells in the presence of elevated levels of cyclic AMP. Glia 8:232-240.

Sonnenberg E, Weidner KM, Birchmeier C (1993) Expression of the nct-receptor and its ligand HGF-SF during mouse embryogenesis. Experientia [Suppl] 65:381-394.

Stewart HGS, Eccleston PA, Jessen KR, Mirsky R (1991) Interaction between cAMP elevation, identified growth factors, and serum components in regulating Schwann cell growth. J Neurosci Res 30:346352.

Stewart HGS, Morgan L, Mirsky R, Jessen KR (1993) Changes in DNA synthesis rate in the Schwann cell lineage in vivo are correlated with precursor-Schwann cell transition and myelination. Eur $\mathrm{J}$ Neurosci, in press.

Tashiro K, Hagiya M, Nishizawa T, Seki T, Shimonishi M, Shimizu S, Nakamura T (1990) Deduced primary structure of rat hepatocyte growth factor and expression of the mRNA in rat tissues. Proc Natl Acad Sci USA 87:3200-3204.

Weinmaster G, Lemke G (1990) Cell-specific cyclic AMP-mediated induction of the PDGF receptor. EMBO J 9:915-920.

Wood PM, Bunge RP (1975) Evidence that sensory axons are mitogenic for Schwann cells. Nature 256:662-664.

Yee C, DeFrances MC, Bell A, Bowen W, Peterson P, Michalopoulos GK, Zarnegar R (1993) Expression and characterization of biologically active human HGF by recombinant baculovirus. Biochemistry 32:7922-7931.

Zarnegar R, Michalopoulos GK (1989) Purification and biological characterization of human hepatopoietin A, a polypeptide growth factor for hepatocytes. Cancer Res 49:3314-3320.

Zarnegar R, Muga S, Rahija R, Michalopoulos GK (1990) Tissue distribution of hepatopoietin $\mathrm{A}$ : a heparin-binding polypeptide growth factor for hepatocytes. Proc Natl Acad Sci USA 87:1252-1256. 